\title{
Research on the Link of Regional Geographical Education between Normal University and Senior High School
}

\author{
Jun Hong \\ Dean's office of Southwest Petroleum University, Chengdu, China 610500 \\ 64989598@qq.com
}

Keywords: Regional geography; Link; University; Senior high school; Education

\begin{abstract}
In order to improve the educational quality of geography specialty in normal universities, this paper profoundly investigates the link of regional geographical education between normal universities and senior high school from the aspects of teaching objectives, curriculum setting and practical education. Personnel Training Plan of geography normal specialty in the three universities and geography textbooks of senior high school were collected and analyzed. Questionnaires were made and tested and then distributed to 210 students of geography specialty in three universities of Sichuan province who had completed teaching practice from senior high school. The results show that regional geography education in normal university does not pay enough importance on teaching process, teaching methods, teaching practice, as well as the "emotion, attitude and value" objective, thus the students lack experience of learning process and teaching practice. This paper suggests normal geography specialty of universities to complete their personnel training plan and establish optimization mechanism practice.
\end{abstract}

\section{Introduction}

Regional geography is the extension of natural geography and human geography in senior high school education, it is also the main part of senior high school geography curriculum reform. Under the background of new geography curriculum standard in senior high school, it is very important to study the link between personnel training of the geographical specialty in normal universities and the geographical education in senior high school so as to improve the continuity of geography education, strengthen geography teaching stuff in high school and promote the implement of new geography curriculum standard [1].

At the beginning the of this century, the Chinese Ministry of Education launches a new round of curriculum reform of Geography of senior high school and make the New Geography Curriculum Criteria of Full-time Ordinary Senior High School( New Curriculum Criteria) to comprehensively promote quality-oriented education[2]. How to promote the link between higher geographical education and basic geographical education has become the main point of geographical education research in the background of the new curriculum criteria reform. Foreign studies show that the U.S promotes the link between senior high school and college through "two credit system of senior high school-college" and comprehensive communications of teachers and students of both senior high school and college[3]; Russia promotes the link quality through exchanging teachers and setting professional courses and elective courses by colleges and communications[4]. Another research about "society specialty" (History and Geography) of Japanese senior high school shows that the teaching reform of "society specialty" of senior high school in Japan pursues institutional diversification and lacks of the efficient connection with colleges, thus leading to the serous utilitarian thoughts of students in senior high school which can not meet the requirement of higher education[5]. Therefore, this study takes geographical science major of Sichuan Normal University, China West Normal University and Mianyang Normal University as examples, focuses on regional geography and deeply analyzed the educational requirement of new geography curriculum, then explores the link between normal university and the regional geography education in senior high school from the aspects of teaching objectives, curriculum setting and practical education. 


\section{Methods}

Questionnaire. Questionnaires were made and tested by expert method and retest method, and then distributed to 216 geographical normal students who had completed educational teaching practice in high school. 210 valid questionnaires were recovered, accounting for $97.2 \%$.

Document and Literature. Related literature were collected and analyzed including high school textbooks of "Geography 3", the New Curriculum Criteria of senior high school and related academic papers about the link between high school and universities, the Personnel Training Plan of geographical normal specialty of the referring three universities.

Interview. Fourteen Regional Geography teachers in universities and senior high schools, and ten graduates of Geography Normal Specialty were interviewed to deeply explore the present situation and reason of the link of regional geographical education between normal universities and senior high school.

\section{Results and Analysis}

The Link of Educational Objectives. There are three educational objectives of geographical education in high school, including "knowledge and skills", "process and methods and emotion", and "attitude and value" [6]. The normal geography specialty of universities fulfill the link with the objectives of geographical course of senior high school mainly through perfecting the curriculum design and enhancing teaching practice. In order to profoundly learn about the acknowledge condition of graduate toward the three objectives in teaching fieldwork, this study takes "Geography 3" (regional geography) as example and does a survey. The investigation of normal graduates of geography specialty shows that $22.9 \%$ of them know about the three objectives of senior high school's geography very much; $46.7 \%$ of them know much about it; $21.9 \%$ of them have preliminary knowledge about it; $8.6 \%$ of them have no idea about it. In a whole, as nearly $70 \%$ of them know much about the three objectives, the imparting of teaching on geography objectives of college students make effective.

For "knowledge and skills", $78.6 \%$ of normal students believe they can make their students learn about the main problem of the regional sustainable development and solutions; $69 \%$ of them can make their students know about regional difference; only $43.8 \%$ of them can well teach the knowledge about geography observation. For "progress and method", $65.2 \%$ of them think they can make their students express and analyze learning outcomes; $58.1 \%$ of them let their students have preliminary knowledge about the collection, collation and analysis of geography information; only $41.9 \%$ of them can make their students master how to explore geographical problems. For "emotion, attitude and value", those who think they can make students "care about the geography conditions and environmental development of our country", "improve their environmental awareness to form sustainable development concept", "stimulate their interests and motivation for exploring geography problems" and "to preliminary form the global geographic awareness" and the respective rate is $74.3 \%, 72.4 \%, 54.8 \%$ and $41.4 \%$. It shows that the normal students have greater improvement space of the mastery of the three objectives.

The results above show that the connection between the personnel training requirements of normal Geography Specialty in universities and the objective of geographical course of senior high school takes certain effect and normal students have knowledge about the three objectives of Geography of senior high school to some extent. However, "emotion, attitude and value" is the difficulty of normal students, probably because teachers of universities paid less attention on the objective. In order to solve it, the geography normal specialty need urge teachers to attach importance to teaching process and set good examples for their students in their future work through education and guidance of "emotion, attitude and value".

"Emotion, attitude and value" is the enhancement of the first two objectives. Emotion includes interests, enthusiasm, motivation and sentiment; attitude includes studying attitude and scientific and realistic attitude; value includes the unification of individual value and social value and the unification of human value and natural value [7]. Geography teachers of senior high school 
generally think the first two objectives can be imparted through teaching content and process, while "emotion, attitude and value" seems more abstract, most of which need the emotional transition and demonstration guide of teachers [8]. Therefore, geography education of universities should attach more importance to normal students' education of world view, and teach emotion education method to lay the foundation of their employment in combination with the objective "emotion, attitude and value" of senior high school.

The Link of Curriculum. Chinese Geography, Global Geography and geographic information technology are the key courses for regional geography education in normal universities. The contents of some elective courses of university are correspond to the elective courses in high school such as Geographic Information System(GIS), Remote Sensing(RS), Tourism Geography, Town and Country Planning, Prevention of Natural Calamities, as well as Regional Analysis and Planning[9]. Fig. 1 shows the regional geography curriculum link between normal university and high school. Chinese Geography and Global Geography analyze regional geography from different view, Town and Country Planning can be regarded as methodological course of regional geography, while it is not included in the required courses of normal university. Meanwhile, due to the principal line of "the sustainable development and the relationship between people and land", China West Normal University opens a course named environment protection and sustainable development, in order to strengthen the regional geography curriculum link between normal university and high school.

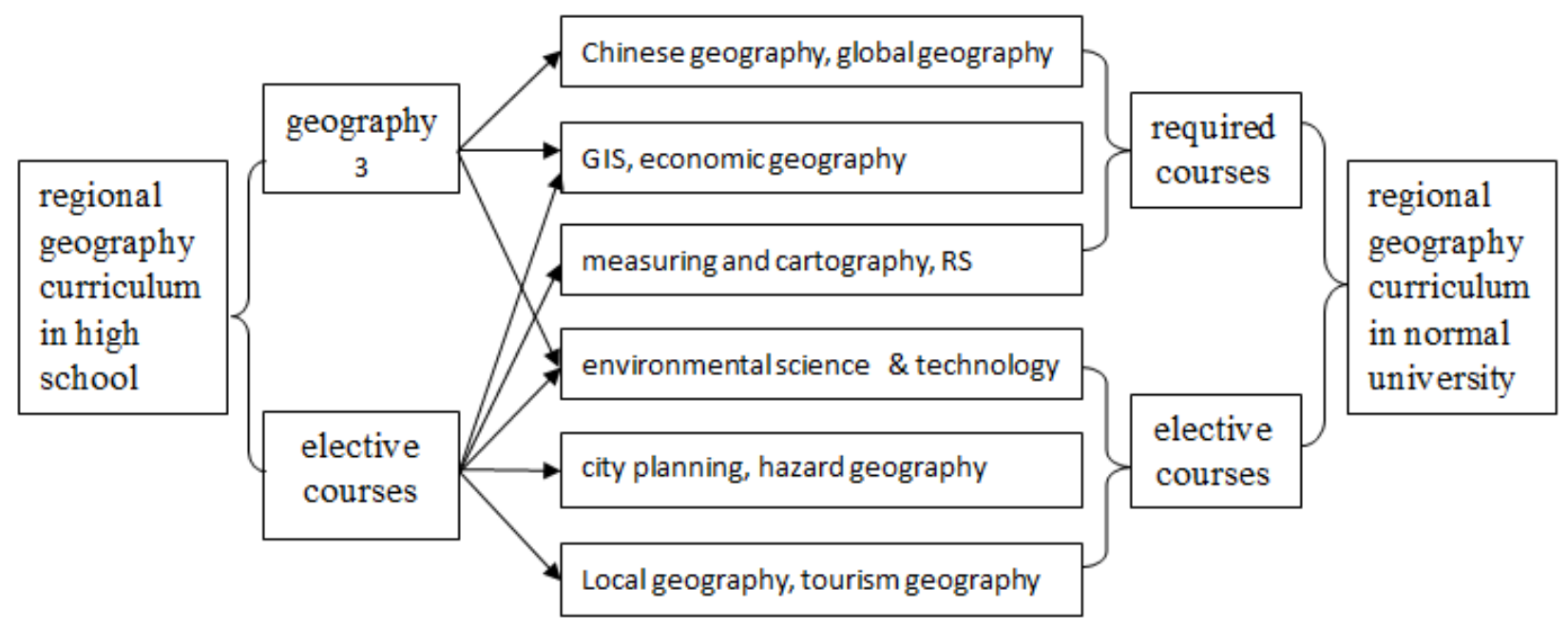

Figure 1. The regional geography curriculum link between normal university and high school

As Table 1 shows, $58.6 \%$ of the students in normal university well mastered the main content of regional geography, $12.2 \%$ of them think them have completely master the content. These results show that regional geography curriculum in normal universities make good effect on the education of regional geography.

Table 1 The level of mastering regional geography contents by graduate students[\%]

\begin{tabular}{ccccc}
\hline contents & $\begin{array}{c}\text { completely } \\
\text { mastered }\end{array}$ & $\begin{array}{c}\text { well } \\
\text { mastered }\end{array}$ & $\begin{array}{c}\text { initially } \\
\text { mastered }\end{array}$ & $\begin{array}{c}\text { not } \\
\text { mastered }\end{array}$ \\
\hline regional environment and human activities & 12.9 & 45.7 & 38.6 & 2.9 \\
regional sustainable development & 8.6 & 51.9 & 35.2 & 4.3 \\
geographic information technology & 11.4 & 46.7 & 33.3 & 8.6 \\
experiments of regional geography & 15.7 & 51 & 29 & 4.3 \\
average & 12.2 & 48.8 & 34 & 5 \\
\hline
\end{tabular}

The Link of Practice. Regional geography is an applied discipline. No matter in the teaching process of China Geography, Global Geography or Local Geography, there are a lot of contents 
closely related to the economic development of our country and the students' real life. The students must carry out extensive practice in order to deeply understand and make reasonable use of regional geography knowledge. So the three universities all have made the schemes for students' professional practice and teaching practice, including field regional geography practice for 1-2 weeks, teaching probation for 1-3 weeks and teaching practice in high school for 6-8 weeks.

Lots of the students majoring geography in normal universities think that the practice arrangement is unreasonable, $30 \%$ of them think the time of teaching practice in high school is too short and the practice should last a full semester, $18.1 \%$ of them think the time arrangement of practice has conflict with writing thesis and applying for a job. Most of the students think the time of regional geography practice and teaching practice is too concentrated, so they hope the universities to increase the practice time and the practice credits for regional geography courses so as to better make use of regional geography theories into practice. The problem above was also investigated by Xiong Pingsheng [10].

Moreover, $58.6 \%$ of the students think themselves lacking the capability of teaching methods although they do increase their teaching ability through teaching practice. $58.1 \%$ and $46.6 \%$ of the students think themselves should strengthen the application of autonomous learning and cooperative learning methods, respectively. In conclusion, the practice still cannot meet the requirements of increasing the teaching ability of students.

\section{Summary}

The normal universities link the regional geography education with high school from the aspects of teaching objectives, curriculum setting and practical education, but universities pay little importance on the teaching process and the guidance of students' emotion, attitude and value, the teaching methods of normal university students should be improved by more practice. So the universities should complete their personnel training plan and establish optimization mechanism practice to strengthen the link with high school.

\section{References}

[1] C. Chen and J. Fan: Interpretation of geography curriculum standard in general senior high school. (Jiangsu Education Press, China 2004) p. 85.

[2] Z. Xu: Education and Vocation, Vol. 28 (2012) No.12, p.114.(In Chinese)

[3] J.C. Li and S.Q. Luo: Educational Development Research, Vol. 21 (2011) No.3, p.47.(In Chinese)

[4] Y.H. Fu: Modern Primary and Secondary Education, Vol. 12 (2014) No.2, p.106.(In Chinese)

[5] B.X. Qiao and H.L., Guo: Historical Teaching Problems, Vol. 24 (2011) No.2, p.60.(In Chinese)

[6] M.X. Chi: Effective Teaching Strategy and the Empirical Analysis of Regional Geography in High School. (MS., Ludong University, China 2014), p.25.

[7] Y. Zhang: Theory and Practice of Contemporary Education, Vol. 4 (2012) No.5, p.111.(In Chinese)

[8] Y. Ma: Geography Education, Vol. 17 (2014) No.9, p.37.(In Chinese)

[9] H. Wang: Higher Education of Sciences, Vol. 10 (2012) No.5, p.141.(In Chinese)

[10]P.S. Xiong: Journal of Mianyang Normal University, Vol. 26 (2007) No.5, p.100.(In Chinese) 